\title{
Ideja zajednice u sociološkoj misli i kršćanska zajednica
}

\author{
Vlaho Kovačević* \\ vkovacevic@ffst.hr
}

https://doi.org/10.31192/np.17.2.2

UDK: 316.334 .52

27:316.334.52

Izvorni znanstveni rad / Original scientific paper

Primljeno: 29. ožujka 2019.

Prihvaćeno: 29. svibnja 2019.

U ovom smo radu, na temelju razumijevanja zajednice kao tradicije (potaknute koncepcijama Ferdinanda Tönniesa) i razumijevanja zajednice orijentirane oko ideje građanske zajednice (prema shvaćanjima Emilea Durkheima), pristupili razumijevanju kršćanske zajednice unutar teorije simboličke zajednice (koju je izvorno koncipirao Victor Turner, a drugačije prikazao Anthony Cohen). Zajedničko je tim različitim pristupima i koncepcijama zajednice u sociološkoj misli ideja da se zajednica tiče pripadanja, poput izražavanja čežnje za zajednicom, traženja smisla i solidarnosti, prepoznavanja i identiteta kolektiva. Odatle i razumijevanje kršćanske zajednice pretpostavlja povijesnu i društvenu mogućnost za društveno djelovanje i kulturnu tranziciju izvan okvira društvene strukture tradicionalne i građanske zajednice, ali i ideje simboličke konstrukcije zajednice određene graničnom konstrukcijom potvrđivanja pojedinca u odnosu prema drugima. Poistovjećujući kršćansku zajednicu s psihološkom dimenzijom pripadanja i solidarnosti, a ona je više simboličko-interaktivna u odnosu preobrazbe prema sebi nego samu sebe potvrđuje u odnosima prema drugima.

Ključne riječi: ideja zajednice, kršćanska zajednica, liminalnost i communitas, moderna sociološka misao, tradicionalna i građanska zajednica.

\footnotetext{
* Doc. dr. sc. Vlaho Kovačević, Sveučilište u Splitu, Filozofski fakultet, Odsjek za sociologiju, Poljička cesta 35, HR-21000 Split.
} 


\section{Uvod}

Jedan od bitnih koncepata utemeljenja sociologije i njezine perspektive $u$ odnosu na društvo jest i ideja zajednice. Opis mogućnosti ideje zajednice u sociološkoj misli u ovom radu otvara nas prema kreativnom paradoksalnom konceptu zajednice u oblikovanju različitih oblika društvenih veza. U izboru klasifikacijskog sociološkog pristupa prikazane su tri najvažnije sociološke paradigme o zajednici: one o shvaćanju zajednice kao tradicije (potaknutu koncepcijama Ferdinanda Tönniesa), one orijentirane oko ideje moralne ili građanske zajednice (prema shvaćanjima Emilea Durkheima) i one vezane za simboličku zajednicu (koju je izvorno koncipirao Victor Turner, a recentnije reformulirao Anthony Cohen). ${ }^{1}$ Odvajajući se iz dualizama shvaćanja zajednice kao tradicije ili građanske zajednice, a one se bave opstankom zajednice u suvremenom društvu, mogućnost vizije kršćanske zajednice prikazali smo prema konceptu i implicitnoj perspektivi simboličke zajednice.

Zahvaljujući zamahu kulturno-antropološkog promišljanja o zajednici na temelju Victora Turnera ${ }^{2}$ i Anthony Cohena ${ }^{3}$ koncepcija simboličke zajednice izvedena je iz već prije razvijene teorije o obredima prijelaza (rites de passage) Arnolda van Gennepa. ${ }^{4}$ Obredi prijelaza nam naznačuju tranziciju »iz jedne situacije u drugu ili iz jednog kozmičkog ili društvenog života u drugi«. ${ }^{5}$ Pritom, shvaćajući prema Turneru, zajednicu kao communitas, pojam koji naglašava društvenu vezu koja postoji u svim vrstama društva i koja se ne može reducirati u zajednicu u smislu fiksnog i prostorno specifičnog grupiranja.

»Drugim riječima, zajednica ima transcendentnu narav i ne može se jednostavno izjednačiti s stanovitim skupinama ili mjestom (...) niti se može svesti na ideju, jer ideje ne postoje jednostavno izvan društvenih odnosa, društvenih struktura ili povijesnog miljea. ${ }^{6}$

U tom smislu ona je pokušaj pronalaženja ravnoteže između imaginirane i simboličke prirode izražavanja čežnje za zajednicom, traženja smisla i prepoznavanja zajednice i njezine stvarnosti kao posebnog oblika iskustva u dijeljenju solidarnosti i pripadnosti.

\footnotetext{
${ }^{1}$ Usp. Gerard DELANTY, Community, London - New York, Routledge, 2018, 34-35.

2 Usp. Victor TURNER, The Ritual Process. Structure and Anti-Structure, London, Routledge and Kegan Paul, 1969.

${ }^{3}$ Usp. Anthony P. COHEN, The Symbolic Construction of Community, London - New York, Routledge, 1985.

${ }^{4}$ Usp. Arnold van GENNEP, The Rites of Passage, Chicago, The University of Chicago, 1960.

${ }^{5}$ Isto..., 10.

${ }^{6}$ Delanty, Community..., 4-5.
} 


\section{Zajednica: struktura ili simbol?}

U globaliziranom društvu pojedinac se nalazi u rascjepu između tradicionalnih, modernih i postmodernih tendencija u društvu. Pod sve većom navalom individualne slobode postupno se gubi sigurnost koju su mu pružali tradicionalni autoriteti, čime je izložen gubitku tradicionalnih obiteljskih, kulturoloških i religijskih uporišta. S obzirom da su strukturalne osnove granice postale narušene ili oslabljene kao posljedica društvenih promjena, nameće se pitanje je li uopće treba raspravljati o zajednici da bi osjećali odgovornost prema okolini te bližnjima i može li nam zajednica pomoći da bismo preuzeli odgovornost za svijet u kojem živimo.

Problem nastaje čim krenemo opisivati ono što spaja ljude, daje im smisao, kako nastaju i dokle idu granice empatije i suosjećanja.

»Takvo stanje, prema Bellu i Newbyju, vjerojatno proizlazi (i) iz činjenice da subjektivni osjećaji koje zajednica pobuđuje u sociolozima (kao i u ne-sociolozima) često vode brkanju onoga što zajednica činjenično jest (empirijska deskripcija) i onoga što bi ona trebala biti (normativna preskripcija).«7

Stoga nije čudno da je pojam zajednice danas jedan od »najneuhvatljivijih i najneodređenijih u sociologiji i do sada je uglavnom bez specifičnog značenja«. ${ }^{8}$

Svu tu širinu, nekonzistentnost i neodređenost koje se vežu uz pojam/koncept zajednice moguće je shvatiti na način da »upravo stoga što je tako elastična i raznolika u svojim značenjima, ideja zajednice nastavlja zaokupljati imaginaciju ljudi, te nastavlja dobivati na važnosti u svojim novim primjenama «. ${ }^{9}$ Dakle, u neodređenosti ne treba vidjeti tek nejasnoću i pomutnju nego, ponajprije, slobodu i otvorenost prema simboličkom smislu da bi rekonstruirali narušenu i oslabljenu granicu spram novih životnih aranžmana te razvojnih i istraživačkih mogućnosti. $^{10} »$ Budući da nijedan pojedini pristup zajednici ne funkcionira najbolje u svim situacijama «, treba »upotrijebiti onaj koji najbolje funkcionira u danoj situaciji.. ${ }^{11}$

Suočavajući se sa zajednicom, dakle, mi se bavimo idejom koja sadrži mnoge mogućnosti i paradokse. Među brojnim proturječnostima zajednice jest i samo razumijevanje zajednice koje neki smatraju kao utvrđenu činjenicu, uzetu za skoro gotovu stvarnost, dok drugi zajednicu smatraju kao misiju da se to postigne. U hrvatskom je socijalnom prostoru, unutar optike dubljih dvaju socijalnih procesa, makar u pojednostavljenom, dihotomnom obliku, moguće naznačiti i u odnosu na kršćansku zajednicu postojanje dviju vrsta zajednica: a) zajednicu

\footnotetext{
7 Marija GEIGER ZEMAN, Zdenko ZEMAN, Uvod u sociologiju (održivih) zajednica, Zagreb, Institut društvenih znanosti Ivo Pilar, 2010, 23.

${ }^{8}$ Nicholas ABERCROMBIE, Stephen HILL, Bryan S. TURNER (ur.), The Penguin Dictionary of Sociology, Harmondsworth, Middlesex, Penguin, 1984, 44.

9 Graham DAY, Community and Everyday Life, London - New York, Routledge, 2006, 1.

${ }^{10}$ Usp. Geiger Zeman, Zeman, Uvod u sociologiju..., 24.

${ }^{11}$ Larry LYON, The Community in Urban Society, Long Grove, Waveland Press, 1999, 2.
} 
starog tipa: ona je religijska, kulturna i socijalna cjelina, a pruža ukočeni otpor svakoj promjeni i u kršćanskoj zajednici i u širem društvu; b) zajednicu novog tipa: u genezi - ne izrasta iz prethodne, ali nastaje kao posebna, samosvjesna. S jedne strane, ona razbija zatečenu cjelinu, a s druge strane, integrira razbijenu zajednicu, suvremenije artikulirajući njezinu strukturu i fizionomiju. ${ }^{12}$

To se događa stoga što često dolazi do zamjene mišljenja što zajednica kao činjenica jest i kakva bi zajednica trebala biti.

»Prvu poziciju zastupaju Abramsi McCullouch, ${ }^{13}$ kada opisuju zajednicu kao 'obuhvatnu društvenu činjenicu' življene međusobne ovisnosti koja izaziva osjećaje simpatije i solidarnosti kroz društvene odnose koji su uglavnom nesvjesni i koji stoga imaju tendenciju da daju individualni izbor i volju. Ovdje se zajednica nameće ljudima.. $\aleph^{14}$

»Međutim, ovu prilično fatalističku interpretaciju osporavaju drugi koji grade zajednicu kao nešto što ljudi aktivno promišljaju, kao 'metaforu za ljude koji žude za boljim životom' i 'imaginarnim okvirom za političku mobilizaciju' ili kao mjeru jaza između života kojeg je moguće iskustvom proživljavati i života kakav se može zamisliti.«15

Dakle, to se zbiva u kontekstu brzo promjenjivog društvenog svijeta, vremena velike tekuće postmodernosti koju obilježavaju individualizacija, raspad etičkih konteksta, slabljenje autoriteta i nedostatak duhovne vlasti koja bi poništila druge glasove.

Pretpostavlja se da je došlo do preobrazbe u središnjem značenju zajednice, od prvog tumačenja do drugog: od osiguravanja sigurnog i stabilnog stanja za svakodnevne društvene odnose na stanje u kojemu zajednica metaforički ili ideološki govori o tome što različiti skupovi ljudi pokušavaju postići, suočeni s realnošću koja izgleda kao da je sve fragmentirano, fluidno i kaotično. ${ }^{16}$

$\mathrm{S}$ jedne strane, to čini veliku šansu za čovječanstvo jer nekad je našim moralnim životom vladao etički kodeks koji je pretendirao na to da ga se općenito prihvaća, pri čemu to prihvaćanje nije bilo vezano uz moralnost već je to bio konformizam. S druge pak strane, navedeni procesi jesu i velika opasnost jer mogu dovesti do masovnog osjećaja nesigurnosti, nestabilnosti i krize identiteta. ${ }^{17}$ Dakle, temeljni motivi u stvaranju zajednice nisu na razini socijalnih formi, već u vitalnoj transformaciji ljudi da bi se oni održali u košmaru života s neizvjesnim ishodištima i socijalno prijetećim izazovima.

\footnotetext{
${ }^{12}$ Usp. Esad ĆIMIĆ, Dogma i sloboda, Otvoreno društvo i zatvorena svijest, Beograd, Književne novine, 1985, 152.

${ }^{13}$ Usp. Philip ABRAMS, Andrew McCULLOUCH, Communes, Sociology and Society, Cambridge, Cambridge University Press, 1976, 165.

${ }^{14}$ Day, Community..., 24-25.

${ }^{15}$ Isto, 25.

${ }^{16}$ Usp. isto.

${ }^{17}$ Usp. Bauman ZYGMUNT, Community. Seeking Safety in an Insecure World, Cambridge, Polity Press, 2001.
} 


\section{Razumijevanje ideje zajednice kao tradicije}

Izjednačavanje zajednice $s$ tradicijom povezano je $s$ idejom o (ponovnom) ostvarivanju zajednice u kojoj prevladavaju primarni odnosi, u kojoj svatko svakog poznaje, u kojoj se mogu kontrolirati okviri vlastite egzistencije. ${ }^{18}$ Može se, štoviše, ustvrditi da su se $»$ mnoge od velikih koncepcija zajednice u zapadnoj misli« bavile "ponovnim zadobivanjem onoga što je bilo izgubljeno «. ${ }^{19}$ Vjerojatno su u pravu oni autori koji drže da ta ideja svoje korijene ima i u židovskoj i u kršćanskoj ideji spasenja kao oporavka ili regeneracije nečeg dragocjenog što je nekoć izgubljeno. ${ }^{20}$

Zajednica je kao otjelovljenje tradicije kultivirala modernu sociološku ideju zajednice kao primordijalnog i integrativnog svijeta koji blijedi s dolaskom modernosti ${ }^{21} \mathrm{i}$ koji se neizbježno raspada pred snažnim i nezaustavljivim naletima modernizacije. Glavno oruđe modernizacije jest totalna racionalizacija sveg društvenog života (koncept racionalizacije je na prijelazu iz 19. u 20. stoljeće posebno dojmljivo i dalekosežno utjecajno razvio Max Weber). ${ }^{22}$

U tom intelektualnom i svjetonazorskom kontekstu nastaje i najpoznatije djelo o zajednici kao tradicionalne kulturne vrijednosti Ferdinanda Tönniesa, Zajednica i društvo, izvorno objavljeno u Njemačkoj 1887. godine pod naslovom Gemeinschaft und Gesellschaft. ${ }^{23}$ Središnju ideju Zajednice i društva je u predgovoru knjige formulirao Pitirim Sorokin istaknuvši da je Tönnies zamislio i konceptualizirao Gemeinschaft i Gesellschaft kao »dva različita modusa mentaliteta i ponašanja i kao dva različita tipa društva« ${ }^{24} \mathrm{Na}$ početku djela, Tönnies raspravlja da su društvo i zajednica različiti izrazi društvenih odnosa koji se mogu shvatiti kao proizvod ljudske volje. ${ }^{25}$

Prema Tönniesu bit obaju tipova Gemeinschaft i Gesellschaft pronađena je i isprepletena u svim vrstama asocijacija. Prva je više ukorijenjena u položaju i "prirodna «, dok je druga više "racionalna«, mentalni proizvod i onaj koji se održava odnosima razmjene. ${ }^{26}$ To pokazuje činjenicu da u temeljima Tönniesove koncepcije stoji dihotomija - dvočlana (binarna) opozicija različitih tipova društvene organizacije. Time Tönnies predvodi niz sociologa koji su o društvu

\footnotetext{
${ }^{18}$ Usp. Ognjen ČALDAREVIĆ, Čikaška škola urbane sociologije. Utemeljenje profesionalne sociologije, Zagreb, Hrvatsko sociološko društvo, 2012, 34.

${ }^{19}$ Delanty, Community..., 20.

${ }^{20}$ Usp. Geiger Zeman, Zeman, Uvod u sociologiju..., 16.

${ }^{21}$ Usp. Delanty, Community..., 35.

${ }^{22}$ Usp. Geiger Zeman,Zeman, Uvod u sociologiju..., 34.

${ }^{23}$ Usp. Ferdinand TÖNNIES, Community and Society, New York, The Michigan State University Press, 1957.

${ }^{24}$ Pitirim SOROKIN, Foreword, u: Tönnies, Community and Society..., VII.

${ }^{25}$ Usp. Ferdinand TÖNNIES, Community and Society, New York, Harper \& Row, 1963, 33.

${ }^{26}$ Usp. isto, 249.
} 
mislili pomoću antitetičkih tipologija, no ta vrsta konceptualizacije u svojoj biti nije originalna i mnogo je starija od konca 19. stoljeća. ${ }^{27}$

Drugi primjer shvaćanja zajednice kao ponovno ostvarive u modernoj sociološkoj misli moguće je vidjeti u

»ideologiji nacionalizma, koja je ideju političke zajednice uvijek povezivala s primordijalnom kulturnom zajednicom. Prema nacionalističkom konceptu zajednice, nacija - koja je najbolje otjelovljena u političkom obliku države postoji samo kao izraz jedne prvobitnije zbilje: kulturne zajednice oblikovane zajedničkom poviješću, jezikom, običajima itd. $^{28}$

Kulturno-identitetsko razumijevanje društvenog konteksta zajednice u ideologiji nacionalizma moguće je povijesno promatrati kao labirint znakova kulture, kao sredstvo i svrha identiteta koji se stalno i iznova konstruiraju. ${ }^{29}$

\section{Razumijevanje ideje zajednice kao moralne ili gradanske zajednice}

Druga važna paradigma o zajednici u modernoj sociološkoj misli jest ona koja se usmjerila oko ideje moralne zajednice, a bila je potaknuta koncepcijama Emilea Durkheima. On je bio polemički nastrojen spram Tönniesovih shvaćanja. Zapravo, u svom najznačajnijem djelu O podjeli društvenog rada, objavljenom 1893. godine, učinkovito preokreće Tönniesovu tezu tvrdeći da se tek u modernosti pojavljuju doista učinkoviti oblici solidarnosti, koji zamjenjuju prošle, mehaničke oblike. Osim toga, on nije prihvaćao Tönniesovo uvjerenje da se samo država može učinkovito suprotstavljati destruktivnim učincima individualizma koji karakterizira moderno doba, a odbijao je i uvjerenje da su individualizam, interes i različitost nužno loši, postavljajući pitanje koji je moralni poredak najsposobniji sučeliti se s problemom suvremenog doba. ${ }^{30}$

U djelu O podjeli društvenog rada on tako ustvrđuje da je društvo »nužan uvjet« morala, jer »moral se, u svim svojim stupnjevima, uvijek nalazio jedino u društvu, uvijek se mijenjao ovisno jedino o društvenim uvjetima «. ${ }^{31}$ Reagirajući na turbulencije i kaos prijelaza iz predmodernog u moderno društvo, cijela njegova sociologija pokušavala je odgovoriti na pitanje kakva društvena inte-

\footnotetext{
${ }^{27}$ Usp. Sorokin, Foreword..., VII-VIII; John G. BRUHN, The Sociology of Community Connections, Dordrecht i dr., Springer, 2011, 29.

${ }^{28}$ Geiger Zeman, Zeman, Uvod u sociologiju..., 16-17.

${ }^{29}$ Usp. Vlaho KOVAČEVIĆ, Kulturno-identitetske odrednice bosansko-hercegovačkog društvenog konteksta, u: Ivica ŠARAC (ur.), Identiteti - kulture - jezici. Kulturna i identitetska raznolikost BiH - europske perspektive jednoga podijeljenog društva. Zbornik radova, Mostar, Filozofski fakultet, 2015, 67-86, 69.

${ }^{30}$ Delanty, Community..., 41.

${ }^{31}$ Veljko CVJETIČANIN, Rudi SUPEK, Emile Durkheim i Francuska sociološka škola, Zagreb, Naklada Ljevak, 2003, 157-158.
} 
gracija može postojati u suvremenom društvu. Temelj sociologije je pronašao u pojmu zajednice koja je specifična za modernost, a ona se može shvatiti kao oblik moralnog individualizma. Valja napomenuti da takve zajednice donose nove tradicije i stoga su tek relativno post-tradicionalne. ${ }^{32}$ Durkheim izrijekom poručuje: »Jednom riječju, sada nam je prva dužnost stvoriti moral.«33 Moralni individualizam time postaje nova vrsta građanskog morala koja bi mogla biti sposobna suzbiti egoistični individualizam. ${ }^{34}$

»Da bi opisao stanje u društvu koje se ubrzano modernizira, Durkheim rabi pojam anomije, pod kojim misli raspadanje, konflikt ili nepostojanje društvenih normi, a povezuje je s neredom, krizom (ponajviše u poznatom djelu Samoubojstvo, objavljenom 1897. godine pod naslovom Le suicide)..135

Pridjev anomos doslovce znači »bez zakona«, »izvan zakona«. Fenomen samoubojstva, antisemitizam i ekstremni nacionalizam $u$ ranom dvadesetom stoljeću mogu se navesti kao primjeri patoloških posljedica odsutnosti ili obožavanja odgovarajućeg oblika zajednice u suvremenom društvu. Pritom se ponovno vraća starijim oblicima zajednice, ali oblicima koji nisu prikladni za zahtjeve modernosti. U razumijevanju ideje zajednice kao moralne ili građanske zajednice,

»za razliku od mita tradicionalne zajednice, naglasak je na zajednici kao moralnoj sili koja je bitno građanska u prirodi. Uloga tradicije relativno je nevažna, jer je tradicija ponovno stvorena s modernitetom. (...) Dakle, razlika između sadašnje i prošle nije nestanak zajednice, već nastanak nove vrste zajednice.« ${ }^{36}$

\section{Razumijevanje ideje simboličke zajednice}

Većina klasične tradicije u sociologiji bavi se problemom opstanka zajednice, kako smo vidjeli, unutar zajednice kao tradicije ili kao građanske zajednice u suvremenom društvu. Koncepcija simboličke zajednice odvaja se iz dualizma zajednice i društva koja je često bila značajka tih djela. Tradicionalna zajednica, kako je opisao Tönnies, uglavnom je utemeljena na nehotičnim vezama. Društvo je drukčije, zahtijeva više svjesnog napora i racionalnih oblika djelovanja.

Prema Schmalenbachu možemo razlikovati fenomen »zajedništva« kao sociološku kategoriju, različitu od zajednice i društva da bi ukazali na emocionalna iskustva unutar mnogo zajednica ${ }^{37}$ (npr. festivali, karnevali, obredna

\footnotetext{
${ }^{32}$ Usp. Delanty, Community..., 41.

${ }^{33}$ Cvjetičanin, Supek, Emile Durkheim..., 166.

${ }^{34}$ Usp. Delanty, Community..., 41.

${ }^{35}$ Geiger Zeman, Zeman, Uvod u sociologiju..., 37-38.

${ }^{36}$ Delanty, Community..., 42-43.

${ }^{37}$ Usp. Herman SCHMALENBACH, On Society and Experience, Selected Papers, Chicago, University of Chicago Press, 1977.
} 
stanja, rituali, sve što nije svakodnevni život i stanja u kojem je svakodnevni život prekinut). Ovaj potonji pristup zajednici osobito je važan za razumijevanje fluidnijih, afektivnijih i svečanih izraza zajednice kao zajedništva, a odražava se u konceptu communitasa Victora Turnera kao spontanog, zajedničkog osjećaja, sličnog Durheimovoj »kreativnoj uzavrelosti «. ${ }^{38}$ Durkheimova centralna i trajna briga, kao što smo u prethodnom poglavlju vidjeli, bila je solidarnost s pronalaskom veza koje bi mogle neraskidivo povezati članove društva. Podjela rada u kojoj su različite funkcije sažete u produktivnu cjelinu omogućava da su točke različitosti koje dijele ljude transformirane u međuovisnosti koje ih ujedinjuju. ${ }^{39}$

Osnovno djelo Victora Turnera, Ritualni proces: struktura i antistruktura, objavljena 1969. godine pod naslovom The Ritual Process: Structureand AntiStructure je preusmjerila antropološko proučavanje zajednice. ${ }^{40}$ Autor je najpoznatiji prvenstveno po slavnoj raspravi o liminalnosti, konceptu posuđenom iz ranijih djela Arnolda Van Gennepa. ${ }^{41}$

»Liminalnost se odnosi na one trenutke 'između', poput karnevala, hodočašća, obreda prijelaza ili rituala u kojima je normalnost suspendirana. Liminalnost 'momenti u vremenu i izvan vremena' - često se povezuje s onim momentima simboličke obnove kada društvo ili grupa ističu svoj kolektivni identitet.«22

Prema Turneru »ovi trenuci mogu postati visoko institucionalizirani - kao u crkvenim obredima - oni su izražajnost kreativnosti i izvode važne društvene funkcije «. ${ }^{43}$ Victor Turner raspravlja o liminalnosti ne samo unutar simboličkih termina nego kao izraz zajednice, a nju shvaća kao communitas, pojam koji naglašava društvenu vezu koja postoji u svim vrstama društva. ${ }^{44}$ Turnerov argument o zajednici jest da se zajednica mora razumjeti suprotno strukturi i ne može se reducirati u zajednicu u smislu fiksnog i prostorno specifičnog grupiranja. »Communitas je poduprt 'anti-strukturama', kada se 'strukture' odupiru. Pojavljuje se kada anti-strukture dolaze u igru. $\aleph^{45}$ Drugim riječima, sama naša nazočnost u smislu fiksnog i prostorno specifičnog grupiranja nije dovoljna jer mi nismo samo pozvani tu biti. Turner, dakle, zajednicu razumijeva suprotno strukturi, protiv normi i vlasti institucionalizirane i apstraktne prirode društvene strukture. »Communitas razbija međuprostore strukture, u liminalnost; na rubovima strukture, u marginalnost; i ispod strukture, $\mathrm{u}$ inferiornosti.« ${ }^{46}$ Communitas kao izraz zajednice nije samo karakterističan za

\footnotetext{
${ }^{38}$ Usp. Delanty, Community...,48.

${ }^{39}$ Usp. Cohen, The Symbolic Construction of Community..., 20.

${ }^{40}$ Usp. Turner, The Ritual Process...

${ }^{41}$ Usp. Gennep, The Rites of Passage...

${ }^{42}$ Delanty, Community..., 48.

${ }^{43}$ Isto, 48-49.

${ }^{44}$ Usp. Turner, The Ritual Process..., 96, 130.

${ }^{45}$ Delanty, Community..., 49.

${ }^{46}$ Turner, The Ritual Process..., 128.
} 
predmodernistička društva; to nije ni anti-moderna ni antiteza prema društvu. Prema Turneru, communitas ima kognitivnu i simboličku ulogu:

»Liminalnost, marginalnost i strukturalna inferiornost su uvjeti u kojima su pretežno rađaju mitovi, simboli, rituali, filozofski sustavi i umjetnička djela. Ovi kulturni oblici pružaju ljudima nizom predložaka ili modela koji su, na jednom nivou, periodične reklasifikacije stvarnosti i čovjekove veze prema društvu, prirodi i kulturi. Ali oni su više od klasifikacije, budući da oni potiču ljude na akciju kao i na mišljenje. $\ll^{47}$

Za Turnera, zajednica ima i simboličan karakter u smislu stvaranja snažnih društvenih veza - mi - kao prolazna i liminalna između članova društva ili društvene skupine. Njegova teorija naglašava obvezujuću prirodu zajednice kao spontanog communitasa, a ona je uvijek jedinstvena i stoga društveno prolazna. $^{48}$

Anthony Cohen, u važnoj knjizi Simbolička izgradnja zajednice, objavljena 1985. godine pod naslovom The Symbolic Construction of Community, mnogo duguje Turneru nudeći prikaz društvene zajednice koja ističe svoju simboličku narav. Anthony Cohen zajednicu ne promatra kao nešto što ima strukturu koja se može objektivno definirati i opisati. Umjesto toga simboličku zajednicu on pokušava razumjeti putem iskustava njezinih članova, te onoga što ona znači svojim članovima.$^{49}$ Pojedinac definira sam sebe u odnosu na druge pojedince i kulturu izvan zajednice te kulturu i zajednicu u kojoj živi. »Ljudi su ti koji simbolički konstruiraju zajednicu, čineći je resursom i spremištem značenja kolektivnog, ali i osobnog identiteta. $\aleph^{50}$ Prema Cohenu, zajednica se temelji na simboličnoj konstrukciji granica i to može imati različita tumačenja o značenju communitasa..$^{51}$ Kako je prethodno istaknuto:

»Cohen definira zajednicu u smislu da određene vrste grupa imaju svijest o sebi u odnosu na druge skupine. Najznačajnija vrsta svjesnosti je simbolizacija veza s kojima zajednica razlikuje sebe od drugih. Simbolizacija je afirmacija postojećeg reda od zajednice s pomoću tih graničnih konstrukcija.. ${ }^{52}$

Govoriti o tome što granica znači ljudima, točnije o značenju koje im daje, simbolički je aspekt granice zajednice i, u mjeri u kojoj težimo razumjeti važnost zajednice $u$ iskustvu ljudi, ona je najvažnija. »Simbolički izraz i afirmacija granice povećava ljudsku svijest i osjetljivost prema njihovoj zajednici.«53 Prema tom tumačenju, zajednica u konačnici postoji u simboličkom poretku, a ne u objektivnoj stvarnosti; to je oblik »svijesti o zajednici« i kao takva zajednica

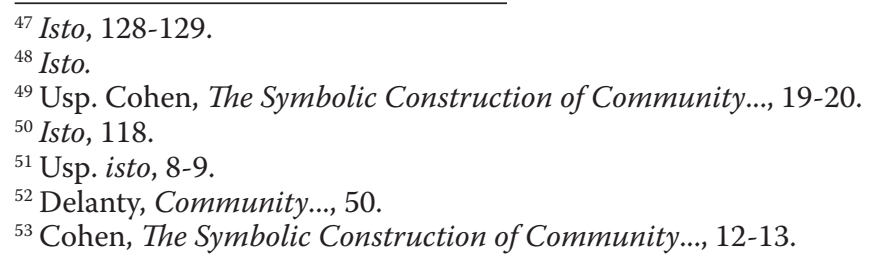


je »obuhvaćena u percepciji svojih granica«, iz čega slijedi zaključak da je u zajednici uvijek riječ o »simboličkoj konstruiranoj stvarnosti«. ${ }^{54}$

Cohen smatra da »ljudi mogu sudjelovati unutar »istog " rituala, ali ipak naći različita značenja za to «. ${ }^{55} \mathrm{U}$ tom smislu zajednica je i ideal i simbolička stvarnost, a značenje je simboličke stvarnosti da ono nema objektivan sadržaj ili vlastito značenje. Oblik simboličke stvarnosti može ustrajati, ali njezino značenje tog oblika može se promijeniti.

»To daje simboličkim oblicima svestranost koja im omogućuje da se prilagode promijenjenim okolnostima. (...) Ova interpretacija zajednice kao simboličke, odstupa od konvencionalnih prikaza u mnogim aspektima, u rasponu od ideje tradicionalnih zajednica do pojma građanske zajednice. Također potencijalno oslobađa zajednicu od mjesta postojanja. ${ }^{56}$

Premda lokalne zajednice postoje kao jači referenti, kao što su institucionalizirani društveni aranžmani ili osobitosti koje se ne mogu tako lako odbaciti. Ali ako je zajednica samo simbolički konstruirana stvarnost, ona se može lakše preobraziti kako to okolnosti zahtijevaju poprimajući simboličan smisao. Dakle, »zajednica nije rigidna struktura, nego je »tekuća« i živa tvorba, u stalnoj mijeni.$^{57}$ Cohen time vjeruje da zajednica može podnijeti promjenu dok se čini nepromjenjivom i stoga je izvor stabilnosti u prolaznosti. ${ }^{58}$

»U ovom pristupu »zajedništvo « koje je nađeno u zajednici ne treba biti jednoliko. Ono ne klonira ponašanje ili ideje. To je zajedništvo oblika (načina ponašanja) čiji sadržaj (značenja) mogu znatno varirati među njezinim članovima.« ${ }^{59}$

\section{Zaključak}

Promjena položaja zajednice u suvremenom hrvatskom društvu je očita kroz sve aktivniju ulogu kršćanske zajednice u javnom i političkom životu Hrvatske. To je zahvatilo promjene u društvenom djelovanju, javnom obavljanju ceremonija, osnivanju odgojnih i obrazovnih ustanova te pristupu sredstvima društvene komunikacije. ${ }^{60}$ Institucionalna dimenzija kršćanske zajednice uključila se u političku stvarnost Hrvatske kao ključan faktor izgradnje nacionalnog identiteta. Suvremeni društveni kontekst hrvatskog društva izravno je time povezan $\mathrm{s}$ ulogom kršćanske zajednice u prošlosti kao i s prirodom društvenih procesa u sadašnjosti koji su uvelike utjecali na društvene funkcije religije. Tranzicija u

\footnotetext{
${ }^{54}$ Usp. isto, 13.

${ }^{55}$ Isto, 55.

${ }^{56}$ Delanty, Community..., 51.

${ }^{57}$ Geiger Zeman, Zeman, Uvod u sociologiju..., 40.

${ }^{58}$ Usp. Delanty, Community..., 51.

${ }^{59}$ Cohen, The Symbolic..., 20.

${ }^{60}$ Vine MIHALJEVIĆ, Društveni kontekst i teorijsko-hipotetski okvir istraživanja »Novi laički crkveni pokreti u Hrvatskoj«, Zagreb, Institut društvenih znanosti Ivo Pilar, 2005, 12.
} 
suvremenom hrvatskom društvu pokazuje promjenu položaja kršćanske zajednice u društvu, a transformacija promijenjenu religijsku situaciju koja ističe odnos prema vjeri i veći stupanj poistovjećivanja nacionalnog i vjerskog. ${ }^{61}$ Između nacionalnog i religijskog bića je nastala tolika isprepletenost i međuovisnost da su se gotovo poistovjetili. ${ }^{62}$

Zajednica se stoga počesto razumijeva u smislu pojednostavljenog povratnog utjecaja rezultata svjetonazora čvrsto utemeljena u sintezi racionalnog, običajnog, religijskog, zakonomjernog itd. ${ }^{63} \mathrm{U}$ društvenom pamćenju je hrvatskog društva time društvena struktura zajednice starog tipa povijesno izravno povezana s autoritarizmom na političkom području, a na kulturnom području tradicionalizmom. ${ }^{64}$ Percepcija se simboličke zajednice, $\mathrm{u}$ odnosu na prethodno stanje u hrvatskom društvu, može promatrati unutar tranzicije društvenog života zajednice u Hrvatskoj kao otvoren sustav kulturne interpretacije, a on ovisi o njezinim članovima. U tom pogledu, simbolička zajednica kao kulturni oblik zahtijeva razumijevanje njezinih članova i njezina svestranost proizlazi iz činjenice da nije zatvoren sustav, ali zahtijeva od svojih članova razumijevanje značenja kolektivnog, ali i osobnog identiteta.

Rušenjem starog poretka pod nemilosrdnim udarima industrijalizacije i demokratske revolucije organizacija ljudskog života sve se "više oblikuje kao subjektivacija društva, društvo kao subjekt, kojemu više nisu potrebna transcendentna, kako prirodna tako i religijska jamstva opstanka «. ${ }^{65}$ Otuda je pristup društvu kod »klasičnih sociologa" predmet znanstvene analize iz duha prosvjetiteljskog i industrijskog prijeloma modernosti u kojem »društvo je u stalnom kretanju, a ono što ga održava dolazi iz unutarnje regulacije«. ${ }^{66}$

Temeljna teorija Turnera o zajednici kao communitasu je pogled na ulogu društvenih veza zajedništva, a ovo zajedništvo postoji i unutar normativnih communitasa i ideoloških communitasa. To pokazuje da moderna nosi i jednu osobitu normativnu povijesnu važnost, ${ }^{67}$ a koja ima svoje bitno izvorište $u$ ideologijsko-političkoj sferi. Zato njemački filozof Jürgen Habermas priznaje da je tijekom modernoga nastalo prisvajanje vrijednosnih sadržaja kršćanstva

\footnotetext{
${ }^{61}$ Usp. isto, 12.

${ }^{62}$ Usp. Željko, MARDEŠIĆ, Rascjep u svetome, Zagreb, Kršćanska sadašnjost, 2007, 757.

${ }^{63}$ Usp. Esad ĆIMIĆ, Iskušenja zajedništva, Sarajevo, Did, 2005, 177.

${ }^{64}$ Usp. Vlaho KOVAČEVIĆ, Vrijednosna orijentacija i kršćanske vrijednosti, Nova prisutnost, 12 (2014) 2, 221-238, 226.

${ }^{65}$ Rade KALANJ, Suvremenost klasične sociologije, Zagreb, Politička kultura, 2005, 259.

${ }^{66}$ Jean-Claude KAUFMANN, Iznalaženje sebe. Jedna teorija identiteta, prev. Marko Gregorić (L'invention de soi. Une théorie de l'identité, Paris, Armond Colin, 2004), Zagreb, Antibarbarus, 2006, 318.

${ }^{67}$ Usp. Simon GUNN, History and Cultural Theory, Edinburgh Gate, Pearson Longman, 2006, 109.
} 
i njihova prijenosa u racionalne kategorije za potrebe osamostaljenja svjetovne države i društva ${ }^{6}{ }^{6}$ Habermas ističe da se:

»Proces prisvajanja nataložio $u$ teško opterećenim normativnim mrežama pojmova kao što su odgovornost, autonomija i opravdanje, povijest i sjećanje, novi početak, inovacija i povratak, emancipacija i ispunjenje, izvanjštenje, pounutrenje i utjelovljenje, individualnost i zajednica. « ${ }^{69}$

»To razlikuje procjenu communitasa, nudi važnu korekciju, reducirajući procjenu zajednice i štoviše ima zasluge u povlačenju pažnje kreativne uloge zajednice u oblikovanju različitih oblika društvenih veza. ${ }^{70}$

Podjednako unutar ideologijsko-političke sfere retradicionalizacije ili modernizacije kroz proces detradicionalizacije i sekularizacije koji su, za razliku od spontanih communitasa, unutar ograničenja strukture. Sugerirajući pogled na zajednicu kao anti-strukturalan trenutak unutar društva, a on ne dopušta da se pretvori u socijalnu ljušturu ispunjenu isuviše prolaznim, primjerice političkim sadržajima, među pojedincima. ${ }^{71}$ Simbolička zajednica uzrokuje njihovo neposredovano i zajedničko iskustvo jedinstvenog spontanog communitasa izvan raskoraka između ograničenja strukture tradicionalne i građanske orijentacije. Riječ je o simboličkoj zajednici kao spontanom communitasu, a on se u molitvi, hodočašću, postu, dobroti, odgovornosti i žrtvi pokušava u kršćanskoj simboličkoj zajednici razumjeti putem iskustava svojih članova unutar čudesnih bratstva molitve, nade, ozdravljenja, duhovnog rasta, otvorenosti, pomaganja, pravednosti i siromaštva.

Podjednako i unutar instutucionaliziranih crkvenih obreda, primjerice $u$ noći Vazmenog bdjenja. Riječ je o zajednici, a ona u obredu Vazmenog bdjenja postiže zajedništvo na temelju simboličkog smisla »službe svjetla« pred ulaznim vratima same zajednice kroz »blagoslov vatre« - znak života i radosti. Vatra okuplja članove zajednice oko sebe: način razmišljanja, osjećanja, vjerovanja, te se na toj vatri pali velika uskrsna svijeća - simbol Krista Uskrsloga. Članovi zajednice pale od nje svoje svijeće i prenose plamen dalje slušajući Vazmeni hvalospjev uskrsnoj svijeći i sve ono što zajednica znači svojim članovima i oni jedni drugima.

Teorijski okvir opće teorije o obredima prijelaza omogućava nam da se pojedinac ili skupina odvajaju od dotadašnjeg statusa u društvenoj strukturi ili kulturnom stanju zajednice starog tipa. Ne dopuštajući, s jedne strane, da se ono što je već realizirano konzervira i njegova se mjera nameće novoj povijesnoj zbilji, a s druge strane, da čovjek izgubi kolektivno pamćenje u kojem indi-

\footnotetext{
${ }^{68}$ Jürgen HABERMAS, Pretpolitički temelji demokratske pravne države, Europski glasnik, 12 (2007) 12, 190-199, 197.

${ }^{69}$ Isto.

${ }^{70}$ Delanty, Community..., 50.

${ }^{71}$ Usp. Esad ĆIMIĆ, Drama a/teizacije, Zagreb - Sarajevo, Šahinpašić, 2006, 163.
} 
vidua nalazi vlastiti identitet. ${ }^{72}$ A nalazeći se na granici, odnosno pragu (limen) između prethodnog i sljedećeg statusa ili stanja. Prepoznajući reagregaciju ili postliminalnu dionicu vitalne transformacije u obredu u kojoj se pojedinac ili skupina s novostečenim statusom ili stanjem uključuje $u$ »novi svijet.$^{73}$

Spomenuti obred Vazmenog bdjenja sugerira da status u društvenoj strukturi ili kulturnom stanju nije vrlo bitan, jer je to forma prije nego sadržaj. Sadržaj varira među članovima budeći i potičući nadu u potencijale skrivene u ljudima, u ljudskoj osobi da želi opće dobro te da se za to i angažira. Suprotstavljajući se interpretaciji izjednačavanja zajednice s tradicijom kao predmodernim svijetom i ideologijom nacionalizma, koja je ideju političke zajednice, nacije najbolje otjelovila u političnosti današnje kršćanske zajednice. Podjednako tako suprotstavljajući se interpretaciji izjednačavanja razumijevanja pripadanja kršćanskoj zajednici u modernosti kao građanskoj zajednici unutar nove vrste civilne religije i pocrkvenjivanja kao profilacije u klerikalnu organizaciju. Cohen predlaže da umjesto shvaćanja zajednice kao integrirajućeg (sjedinjujućeg) mehanizma, zajednicu treba shvaćati kao agregirajući (skupni) sklop. ${ }^{74}$

Sukladno tome ideja simboličke zajednice u modernoj sociološkoj misli ukazuje na mogućnost za društvenu i kulturnu tranziciju ili (liminalnu) graničnu dionicu u kršćanskoj zajednici. Ukidanje svih razlikovnih značajki društvene strukture (antistrukturalnost) tijekom liminalnog razdoblja izvan uskih okvira tradicionalne i građanske zajednice i njihovih vrijednosti dovodi do privremenoga, spontanoga i ravnopravnog zajedništva pojedinaca. Istodobno ne svodeći zajedništvo na ono pojavno unutar unaprijed zacrtanih teorijskih (ideologijskih) okvira prijepora između ideje tradicionalne i građanske zajednice u društvenoj strukturi, dakle, unutar identifikacije pojedinaca s vrijednosno-ideološkim »fragmentarnim $\ll^{75}$ prostorom liberalističkog individualizma i komunitarnog kolektivizma.

U tom pogledu, zajednica je fleksibilnija nego što se može misliti na prvi pogled. Odmaknuvši se od tradicionalne koncepcije zajednice kao teritorijalno locirane i male cjeline utemeljene na tradicionalnim vrijednostima, prema pogledu zajednice kao izrazu komunikacijskih sila unutar modernosti, prepoznajemo simboličku zajednicu. Očitujući se u tranzicijskoj dimenziji, a ona $\mathrm{u}$ vitalnoj transformaciji odnosa pojedinca prema sebi postaje dio zajednice globalnom svijetu. ${ }^{76}$ Prema tome, to nije pitanje tradicionalnih ili hijerarhijskih kao ni modernih ili liberalnih društvenih odnosa, već modus pripadanja i imaginiranja socijalnih relacija, a one se često izražavaju u simboličkim formama

\footnotetext{
${ }^{72}$ Usp. Ćimić, Dogma..., 108-109.

${ }^{73}$ Usp. Marijana BELAJ, Milijuni na putu. Antropologija hodočašća i sveto tlo Međugorje, Zagreb, Naklada Jesenski i Turk, 2012, 23.

${ }^{74}$ Usp. Cohen, The Symbolic..., 20.

${ }^{75}$ Usp. Papa FRANJO, Lumen fidei - Svjetlo vjere. Enciklika o vjeri (29.VI.2013), Zagreb, Kršćanska sadašnjost, 2013, br. 57.

${ }^{76}$ Usp. isto.
} 
koje nije moguće svesti na institucijski aranžman. Simbolička zajednica stoga pretpostavlja povijesnu i društvenu mogućnost za društveno djelovanje i političku i kulturnu tranziciju društvene strukture ili kulturnog stanja identiteta u kršćanskoj zajednici. Riječ je o mišljenju da je samoidentitet nepobitan aspekt zajednice. ${ }^{77}$

\section{Vlaho Kovačević* \\ Idea of the Community in Modern Sociological Thought and Christian Com- munity}

\section{Summary}

The aim of this paper is three major sociological debates on community that are critically examined: $\left(1^{\text {st }}\right)$ the notion of community as tradition (especially with regard to Ferdinand Tönnies), $\left(2^{\text {nd }}\right)$ the idea of moral community (especially around the work of Emile Durkheim) and $\left(3^{\text {rd }}\right)$ the theory of symbolic community (as proposed originally by Victor Turner and restated by Anthony P. Cohen). They share the same approach and community conceptions in sociological thought and the Christian community with the idea that the community is concerned with belonging such as expressions of longing for community, the search for meaning and solidarity, recognition and collective's identities. The next in the selection of the classification sociological approach of the Tönnies conditions, the community is »alive« and is more entrenched in the position of family life in agreement, in rural life in folklore and in the life of the city in religion. Another important concept of the community is recognized by Durkheim in the failure of modernity to develop a new spirit of community that could be called post-traditional. Hence the understanding of the Christian community presupposes a historical and social opportunity for social action and cultural transition outside the framework of the social structure of the traditional and civic community, as well as the idea of a symbolic construction of a community determined by a boundary construction of individual affirmation in self-other-relations. Identifying the Christian community with the psychological dimension of belonging and solidarity, and it is more symbolic-interactive in relation to the metamorphosis towards itself but it confirms itself in relations with others. Accordingly, the idea of a symbolic community in modern sociological thought points to the possibility for a social and cultural transition or (liminal) boundary section in the Christian community.

\footnotetext{
${ }^{77}$ Usp. Anthony P. COHEN, Epilogue, u: Vered AMIT (ur), Realizing Community, London, Routledge, 167.

* Vlaho Kovačević, PhD, Assist. Prof., University of Split, Faculty of Humanities and Social Sciences, Department of Sociology; Address: Poljička cesta 35, HR-21000 Split, Croatia; E-mail: vkovacevic@ffst.hr.
} 
The abolition of all distinctive features of the social structure (antistructurality) during the liminal period beyond the narrow framework of the traditional and civic community and their values leads to temporary, spontaneous and equal communion of individuals. At the same time, not diminishing the communion of the phenomenon within the predetermined theoretical (ideological) framework of the contradiction between the idea of the traditional and the civic community in the social structure. Thus, within the identification of individuals with the value-ideological »fragmentary« space of liberal individualism and communal collectivism.

Key words: Christian community, community idea, liminality and communitas, modern sociological thought, traditional and civic community.

(na engl. prev. Vlaho Kovačević) 